\title{
Skriv sykepleiefaglig godt - og bli lest! (1:2)
}

\section{Vi kan bli bedre fagforfattere og engasjere flere lesere ved å ha en lett tilgjengelig form på teksten.}

Jan Storø

Dosent

Fakultet for samfunnsvitenskap, Oslomet - storbyuniversitetet

\begin{tabular}{llll|l|l|l|l|l|l|}
\hline Undervisning & Fagutvikling og forskning
\end{tabular}

\section{Hovedbudskap}

Skal du skrive sykepleiefaglige artikler? Her får du gode råd om hvordan du kan skrive godt fagspråk, og hvordan du kan formidle denne typen faglitteratur best mulig. Artikkelen er den første av to.

I to artikler vil jeg ta for meg noen utfordringer knyttet til det å skrive sykepleiefaglige artikler. I denne første vil jeg spesielt se på fagspråk og formidling i denne typen faglitteratur. I den andre vil jeg gå mer konkret til verks og se på konkrete skriveutfordringer.

\section{Formidling er et sentralt element}

Når forfatterne i sykepleiefaget skriver faglig litteratur, har de flere mulige veier å gå. Ett åpenbart valg de kan gjøre, er å lene seg til den akademiske verdenens idealer for forskning og forskningsformidling. 
Da handler det om objektivitet, validitet, reliabilitet, argumentasjon, diskusjon - og en rekke andre idealer. Slike idealer bidrar til at faglige tekster er kunnskapsbaserte, og at de sier noe vesentlig om det temaet de handler om.

\section{三 «Akademiske idealer og idealer for en tilgjengelig form kan oppleves å stå i motsetning til hverandre.»}

Men de kan også stå i veien for den gode formidlingen. En faglig tekst skal også kommunisere med sin leser. Den bør fremstilles på en slik måte at leseren lærer, men helst også slik at leseren engasjeres. Derfor bør fagforfatterne arbeide med formen når de skriver.

Dette er spesielt viktig i den faglitteraturen som ikke bare henvender seg til fagfeller i avgrensede miljøer, men også til fagområdets praktikere og studenter. Akademiske idealer og idealer for en tilgjengelig form kan oppleves å stå i motsetning til hverandre.

Men en slik motsetning er en konstruksjon. Den er ikke naturgitt. Sannsynligvis kan den spores tilbake til ulike fagmiljøers formidlingskonvensjoner- og tradisjoner.

Mitt utgangspunkt for denne artikkelen er at de to danner ulike typer idealer. De handler rett og slett om ulike temaer som begge er interessante for fagforfatteren.

\section{Begrunn valget for deg selv}

I artikkelen vil jeg gi noen synspunkter på skriving, på fagskriving og på formidling. De bygger på mine egne erfaringer som skribent og fagskribent gjennom mer enn tjue år.

Legg merke til at jeg kaller det synspunkter og erfaringer. Jeg hevder ikke å sitte på selve sannheten om hva som er god skriving. Det er heller ikke nødvendig. Skriving er en mangfoldig aktivitet, og det som kan sies om den, er også mangfoldig.

Derfor vil artikkelen inneholde en del råd som du som leser kan velge å bruke, eller forkaste. For nettopp slik er det, at du står fritt. Noe av det som er så fint med skriveråd, er at de både kan følges og forkastes. 
Uansett hva du skulle velge å gjøre, ta deg tid til å begrunne for deg selv hvorfor du gjorde det valget. I begge tilfellene vil du kunne lære noe om skriving (1), og din måte å skrive på.

\section{En fagformidler er en vitenskapsformidler}

Jeg vil argumentere for en variant av rollen og oppgaven «vitenskapsformidler» (science communicator) (2). Etter mitt skjønn er dette en rolle - med tilhørende oppgaver - som bør utvikles i større grad enn den er i dag. De utgjør sentrale deler av et moderne kunnskapssamfunn.

En bredere definisjon fanges opp av begrepet «fagformidler», og dette passer derfor bedre her. Men gitt vitenskapens sterke posisjon i det moderne samfunnet er det vanskelig å se for seg fagformidling som ikke også henter sitt stoff fra vitenskapen.

Én potensiell positiv konsekvens av en styrket fagformidling innen sykepleie kan være at flere praktikere begynner å skrive. Ifølge Stepanski (3) har sykepleiere mye erfaring og kompetanse som kan anvendes for fagskriving. Hun skriver at de likevel vegrer seg, og at de kan trenge hjelp til å begynne å skrive.

Johnston og Brassil (4) peker på behovet for å utvikle en unders $\varnothing$ kende faglig kultur, kombinert med å sikre tilgang til ressurser - for eksempel skrivementorer - for å legge til rette for slik skriving.

\section{Det er spenning mellom teori og praksis}

De praktisk orienterte profesjonene har én særlig utfordring som det er verdt å gå dypere inn i. Den er tett koplet med den generelle utfordringen, det alltid spente forholdet mellom teori og praksis. For noen er disse to prinsipielt ulike, mens for andre er de tett bundet sammen i et dynamisk samspill.

En profesjon som sykepleie vil alltid preges av dette spenningsfeltet. I sykepleie vil to kunnskapstyper alltid følge hverandre tett: evident kunnskap om helse, sykdom, medisiner og behandlingsmåter, og på den annen side nærhetskunnskap om praktisk håndlag, relasjoner og menneskem øter. 
Kanskje kan vi til og med si at de to i samspill med hverandre danner en sentral plattform for faget. Det er mulig å hevde at den utgjør en viktig del av selve grunnlaget i profesjonen, slik den også gjør i de andre profesjonene i helse- og sosialfagene.

Utfordringen jeg nevnte i forrige avsnitt, er knyttet til forholdet mellom det skriftlige og det muntlige nivået i kunnskapsoverleveringer. Ofte er det slik at teori og forskning formidles skriftlig, mens praksis formidles muntlig.

Som en forlengelse av dette - nærmest en naturlig forlengelse, vil noen si - når det skriftlige et større publikum, mens det muntlige stort sett formidles lokalt, i små miljøer. I mange situasjoner vil den skriftlige og teoretisk baserte kunnskapsoverleveringen være høyere ansett enn den muntlige og praktiske.

\section{Mange fagbegreper $=$ faglig klokt?}

Vi kan tenke oss ulike mulige strategier for å formidle kunnskap i denne situasjonen. Jeg skal komme inn på de språklige sidene av dette spørsmålet.

Én mulig strategi er å øke den teoretiske kunnskapens status gjennom å søke så langt opp i det språklige hierarkiet som mulig når den skal beskrives. Der hvor de spesifikke fagbegrepene trives godt, og det er tett med fremmedord i teksten. Det vil kunne sikre statusen til denne kunnskapstypen.

\section{三 «Vanskelig formulert likestilles ofte med sannsynligvis klokt.»}

Vi lever i en verden der denne underlige funksjonen lever i beste velgående: Vanskelig formulert likestilles ofte med sannsynligvis klokt. Problemet som straks dukker opp, er at dette språket ikke kommuniserer særlig bredt, og at det ikke nødvendigvis fanger opp de viktigste problemstillingene i den sykepleiefaglige hverdagen.

\section{Praktisk orientert språk $=$ til muntlig bruk?}

Dermed kan det være verdt å sjekke ut en annen strategi, nemlig å kople sterkere mellom det teoretisk orienterte språket og det praktisk orienterte språket - og undersøke om det er mulig å bevege seg nedover i hierarkiet. 
Og kanskje også, som en del av et slikt strev, å skriftliggjøre det språket som er i bruk i hverdagens mange praktiske, uoversiktlige - og ofte muntlige situasjoner. Det siste ville bidratt til at praksiskunnskap ikke kun forblir lokal og muntlig, men at den også kan formidles på tvers av faglige miljøer.

Sykepleielitteraturen kan ut fra en slik betraktning søke sine lesere i et høyt spesialisert språk med presisjon og teoretisk substans som viktige idealer. Forskningslitteraturen vil ofte befinne seg her. Eller den kan søke lesere i et mer hverdagsnært språk, et språk der idealene går mer i retning av å kommunisere forståelig.

\section{Begge typer språk trengs}

Skillet mellom de to bør ikke være tydelig. Kravet til presisjon og kommunikasjon bør ikke settes opp som prinsipielle motpoler. Sykepleiefaget trenger begge typer språk.

Likevel er det nok særlig det praksisnære språket det er spesielt interessant å se nærmere på. Det er her potensialet for å kommunisere bredt er størst. Dette språket står i fare for å bli innlemmet i presisjonsspråket - og måten det føres på - hvis fagforfatterne ikke tar ansvar for det.

Dermed er vi fremme ved kjernen i denne artikkelens tema. Når vi skriver faglitterært i en profesjonskontekst, er det sentralt å arbeide med hva det er i en slik tekst som kommuniserer godt. Det finnes det gode råd om.

\section{Hvem er leseren?}

Det første jeg vil trekke frem, er spørsmålet: Hvem er leseren? Dette spørsmålet springer ut fra et av de mest anvendte skriverådene, uansett sjanger. Vi skrivere bør fors $\varnothing$ ke å nå våre lesere. Da er det nyttig å finne ut hvem de er, eventuelt hvem vi ønsker å henvende oss til.

I sykepleiefaglige tekster kan vi tenke oss flere typer lesere. En enkel tredeling kan se slik ut: forskersamfunnet, praktikerne, studentene. Den skriveren som ikke tar et bevisst valg om hvem av disse gruppene som er den mest åpenbare lesergruppa, risikerer å ikke nå ut. 
Generelt kan vi si at jo mer entydig teksten snakker til

kollegene internt i forskersamfunnet, jo mer kan den ta i bruk feltets særegne begreper og dets egne sjargonger. På den annen side: Jo mer teksten skal kommunisere til studentene, og særlig bachelorstudentene, jo mer bør den være så åpen og inviterende i språket at den når frem til dem.

\section{三 «Vi skrivere bør forsøke å nå våre lesere.»}

Samtidig er det sentralt at studentene skal lære seg de fagbegrepene som danner feltets spesielle språklighet. Men kanskje skal de ikke lære alle på én gang. Utvikling av faglig begrepsforståelse kan være en langsom prosess som krever at studenten arbeider med den over tid.

Praktikerne kommer i en mellomposisjon. Noen av dem, kanskje de fleste, er godt inne i det spesialiserte vokabularet som forskerne bruker. Men andre er kanskje så innstilt mot den praktiske yrkesutøvelsen at de vanligvis bruker lite tid på å lese fagtekster.

Dermed begrenser deres innsikt seg til de fagspesifikke begrepene som er i omløp på den konkrete arbeidsplassen der de utøver sitt yrke.

\section{Skriv for dem utenfor fagfellesskapet}

Mitt ideal for fagtekster er at de skal kunne leses utenfor fagfellesskapets indre krets. Det er ikke det viktigste idealet. Det viktigste ligger i faglig substans og etterrettelighet, og disse idealene sikres ved å bruke de momentene jeg nevnte lenger oppe.

\section{$\equiv$ ¿Hvis mange utenfor faget kan lese teksten, er det mulig at noen faktisk gjør det.»}

Men, tekstene bør også kunne leses av andre enn fagfellene. Iallfall i så stor utstrekning som mulig. Dette idealet er potensielt nyttig på flere måter. Tre av de viktigste er følgende: Hvis mange utenfor faget kan lese teksten, er det mulig at noen faktisk gjør det. Det vil bidra til at feltets temaer blir bedre kjent i samfunnet.

En tekst som kan leses av andre, kan også leses av nykommerne i feltet - de yngste studentene og andre som trenger kunnskapen. 
Det tredje handler om oss selv, skriverne: Hvis vi legger krefter i å formidle bredt, vil vi sannsynligvis være klarere i vårt budskap. Vi vil med andre ord kunne bli bedre fagforfattere ved å fors $\varnothing$ ke å skrive så klart at vi når bredere ut.

\section{Vær bevisst på valget av sjanger}

Når vi er inne på at det finnes ulike lesere, er det naturlig å gå videre til spørsmålet om sjanger. Gjennom å være bevisst våre valg av sjanger, er det mulig å nå den lesergruppa vi ønsker å kommunisere til.

Noen vil kanskje protestere og hevde at vitenskapelige tekster utgjør en sjanger i seg selv. De vil kanskje si at den binder alle faglige tekster opp via ganske strenge regler.

Mitt utgangspunkt er at en slik påstand er en uproduktiv bruk av sjangerbegrepet. I stedet for å bruke begrepet til å lukke mulighetsrommet, bør vi bruke det til å åpne - til å søke muligheter der de kan finnes.

Den tydeligste sjangerkonvensjonen for vitenskapelige tekster er IMRoD-modellen. Den gir føringer for hvordan forskningsartikkelen bør organiseres, i tråd med mitt oppsett (1, S. 117):

I - Innledning, her skriver forskeren en introduksjon til forskningsstudiet

M - Metode, her viser forskeren til hvilken metode som ble brukt i studien

$\mathrm{R}$ - Resultat, her forteller forskeren hva slags funn eller resultat studien ga

D - Diskusjon, her diskuterer forskeren funnene eller resultatet opp mot annen forskning og teori

Modellen er utarbeidet for å gi en felles standard for vitenskapelig skriving i artikler og rapporter. Til dette formålet har den en viktig funksjon. Forskere og andre lesere over hele verden vil raskt og effektivt kunne sette seg inn i hverandres arbeid når presentasjonen av arbeidet bygger på en slik felles modell. 
Men IMRoD-modellens tydelighet og dens store utbredelse bidrar også til en innsnevring av hva vi forstår med det bredere begrepet fagskriving. Hvis all fagskriving uansett fag, formidlingsinnhold og lesergrupper skal holde seg til denne strenge modellen, vil fagskriverne bli bundet unødvendig på både hender og føtter.

IMRoD-modellen bør først og fremst brukes som mal for konkret formidling av forskningsresultater. Formidling utenfor et relativt avgrenset forskningsmiljø bør få sin egen utforming.

Her er det rimelig å ta mer hensyn til formidlingsinnhold og lesergruppe enn til strengheten i vitenskapelig kommunikasjon beregnet på avgrensede og informerte lesergrupper.

\section{IMRoD-malen passer kanskje ikke alltid}

Forskningsformidling innad (i forskningsmiljøene) og utad (til større lesergrupper) bør skilles som to ulike aktiviteter som styres av ulike krav og idealer. Hensikten med den første av dem er som regel presis rapportering om ny kunnskap som kan bidra til å utvikle forskningen og fagfeltet videre.

Hensikten med den andre er å formidle forskningsbasert kunnskap slik at den kan brukes ute i samfunnet. Det gir andre krav og idealer. I en slik formidling er det sjelden behov for å rapportere om ett bestemt forskingsfunn uten samtidig å vise til en bredere kunnskapsfront.

Denne formidlingen krever en større formidlingsmessig bearbeiding slik at flere lesere kan anvende den kunnskapen som formidles. Et av idealene vil være å kople mellom flere forskningsfunn, flere miljøer og gjerne mellom flere faglige perspektiver.

Den formidlingen jeg snakker om her, har trange kår innenfor en streng IMRoD-mal. Den passer ikke godt inn i den vitenskapelige artikkelformens ramme. Jeg hevder at kanskje heller fagboka er det stedet der den kan utfolde seg (5).

Der er det som regel plass til å skrive om bredden av forsking og faglige teorier samt deres praktiske anvendelse. Det er det mulig å skrive slik at leseren får hjelp til å binde sammen og fordype.

En slik måte å tenke på om formidling er ikke ny. Men den er heller ikke så utbredt at den oppfattes som selvfølgelig. 
Det er mange måter å kommunisere på om forskning $\mathrm{i}$ samfunnet. Og det er mange aktører som påtar seg oppgaven (2) - noen av dem mindre faglig oppdatert enn andre.

Vi kan kanskje ikke forvente at journalister, politikere og andre beslutningstakere skal ha full kunnskap innenfor mange fagfelter. Da er det behov for den faglig sterke formidleren med tilhørighet i feltet, som påtar seg oppgaven å kommunisere ut mot et samfunn.

\section{Ta formidlingen på alvor}

Det er på tide å bevege seg til selve formidlingen. Den skapes ikke automatisk av overordnede krav og idealer til god forskning, heller ikke av gode intensjoner. Formidling er i seg selv en faglig aktivitet som må tas på alvor.

Den fagskriveren som ønsker å være en god fagformidler, må over tid arbeide seg frem til de gode formidlingskvalitetene. Jeg har gjort meg den antakelsen at god formidling kan læres, at den kan utvikles videre gjennom stadig praktisering og trening.

Fagfeltene trenger folk som er villige til å påta seg oppgaven med å formidle fagstoff og se på dette som en hovedoppgave. I mitt perspektiv er dette en like viktig funksjon som forskning.

Jeg har også gjort meg den antakelsen at formidlingskvaliteter er synlige i konkret og praktisk forstand, helt ned i enkelttekster. Derfor vil jeg i neste artikkel se på nettopp dette - formidlingskvalitet i tekst. Jeg vil lene meg spesielt på en av mine yndlingsmentorer på dette temaet. Han heter Stephen King.

Han er kjent som grøsserforfatter, men også skrivebokforfatter (6). Min antakelse er at nettopp en formidler som King kan ha noe vesentlig å bringe (også) til fagformidlere. Ett poeng er å hente inspirasjon til å gjøre språket mykere, uten å miste substansen og tydeligheten i budskapet.

For det er vel ikke noen tvil om at akademisk språk, på samme måte som byråkratisk språk, ofte fremstår som stivt og lite tilgjengelig. 


\section{Referanser}

1. Stor $\varnothing$ J. Du må skrive! Skrivebok for studenter i

barnevern og sosialt arbeid. Oslo: Universitetsforlaget; 2019.

2. National Academies of Sciences, Engineering, and Medicine. Communicating science effectively: a research agenda. The National Academies Press. Washington: NAP; 2017.

3. Stepanski LM. Becoming a nurse-writer: advice on writing for professional publication. Journal of Infusion Nursing: 2002;25(2):134-40.

4. Johnston PA, Brassil KJ. Engaging clinical nurses in manuscript preparation and publication. Nurse Author \& Editor. 2014;24(4):4.

5. Stor $\varnothing$ J. Kronikk: Et universitet trenger bøker.

Forskning.no. 2016. Tilgjengelig fra:

https://forskning.no/skole-og-utdanning-kronikk-kunst-og-

litteratur/kronikk-et-universitet-trenger-boker/1169050

(nedlastet 06.08.2020).

6. King S. Om å skrive - forfatteren og håndverket. Oslo: Aschehoug; 2002. 